\title{
Human Problem Solving in 2008
}

\author{
Zygmunt Pizlo
}

\begin{abstract}
This paper presents a bibliography of more than 200 references related to human problem solving, arranged by subject matter. The references were taken from Psyclnfo database. Journal papers, book chapters, books and dissertations are included. The topics include human development, education, neuroscience, research in applied settings, as well as animal studies.
\end{abstract}

\section{Introduction}

Similarly to what I found two years ago, the ratio of the number of journal papers (165) to the number of journals where the papers appeared (104) is barely greater than one (there were also four book chapters). Both these numbers increased compared to 2006. This could result either from more inclusive selection this year, or from increased publication rate.The former seems more likely. Interestingly, the number of doctoral dissertations increased threefold:from 23 to 70. From among papers and chapters, 78 can be classified as basic research (General, Neuroscience, Animal) and 91 as applied (Developmental, Education, Applied). A different proportion is found for dissertations: 21 can be classified as basic research and 49 as applied.

The low ratio of the number of papers to the number journals is quite unusual. This ratio is definitely much higher for other areas of cognition such as visual or auditory perception, memory etc. The main factor has been the absence of a journal dedicated to problem solving. The Journal of Problem Solving has been around for a couple of years, but this is not long enough to change the situation. Another factor is the absence of the definition of our area. What is problem solving? What is not? Regardless of what the reason is, this situation seems undesirable. With a wide range of journals it is obvious that interpretation of some critical methodological concepts such as experiment, theory, model, or result will vary a lot. Similarly, the quality of research and review process will also vary substantially. In particular, no journal has a large pool of reviewers who are experts in any particular sub-area of problem solving and who are easily accessible. As a result,

Purdue University, Department of Psychological Sciences, 703 Third Street, West Lafayette, IN 47907-2081 Email:pizlo@pysclops.psych.purdue.edu

The Journal of Problem Solving • volume 2, no. 1 (Spring 2009) 
the authors are not likely to get the best possible review and criticism of their papers. This is already different with respect to combinatorial problems. Our journal has published a number of papers, and editors of other journals already know about our group. So, regardless of where a paper on the Traveling Salesman Problem is submitted, it is easy now to find the expert reviewers. Although JPS started with a focus on combinatorial problem solving, it had ambition to include all research on problem solving. This may be impossible to achieve considering the fuzziness of the definition of our field. But the next step could be to include a few other welldefined subareas of problem solving. Insight, causality, and mathematics education are good candidates. A somewhat different view was offered by one of the editors of JPS (Robert Goldstone). According to him, it is not bad for problem solving to have papers in so many different journals. In fact, reaching out to many communities could be a good thing for the field. The value of JPS would be to reach out to these different communities to connect researchers that might not otherwise read each others' work. It seems that regardless of the assessment of the current situation in problem solving research, JPS is likely to fill a niche and play an important role. Some of these issues have already been discussed at our recent workshop: http://spiderman.psych.purdue.edu/problem_solving/workshop08/, and more light will be shed on them by papers that we expect to receive for the special issue summarizing the workshop.

\section{List of Journals}

(The number of publications for each journal is shown in parentheses.)

Acta Psychologica

Acta Psychologica Sinica

Advances in child development and behavior

Aging, Neuropsychology, and Cognition (3)

American Journal on Mental Retardation

American Journal of Psychology (2)

American Psychologist

Animal Behaviour

Animal Behavior Processes

Animal Cognition (3)

Applied Intelligence (2)

Axiomathes: An International Journal in Ontology \& Cognitive Systems

Behavioral and Brain Sciences

Behavioural Processes

Behavior Research Methods (2)

Brain and Cognition (4)

Brain Research

British Journal of Developmental Psychology

British Journal of Psychology

- volume 2, no. 1 (Spring 2009) 
Canadian Journal of Experimental Psychology

Cerebral Cortex

Clinical Neuropsychologist (2)

Cognition

Cognition and Instruction

Cognitive Psychology (2)

Cognitive Science (4)

Communication Monographs

Computers \& Education (7)

Computers in Human Behavior (8)

Contemporary Educational Psychology (2)

Creativity and Innovation Management

Developmental Psychology

Early Child Development and Care

Educational Psychology

Educational Psychology in Practice

Educational Research

European Journal of Cognitive Psychology

European Journal of Neuroscience

European Journal of Psychology of Education

European Journal of Social Psychology

Evolutionary Psychology

Experimental Brain Research (2)

Experimental Psychology

Group Processes \& Intergroup Relations

High Ability Studies

Intelligence

Intelligent Data Analysis

International Journal of Artificial Intelligence in Education (3)

International Journal of Behavioral Development

International Journal of Cognitive Informatics and Natural Intelligence

Japanese Journal of Educational Psychology

Japanese Journal of Psychology

Journal of Applied Measurement

Journal of Behavioral Education

Journal of Clinical and Experimental Neuropsychology

Journal of Cognitive Neuroscience (2)

Journal of Comparative Psychology 
Journal of Computers in Mathematics and Science Teaching

Journal of Educational Computing Research (2)

Journal of Educational Psychology (3)

Journal of Experimental Child Psychology (4)

Journal of Experimental Psychology: Animal Behavior Processes

Journal of Experimental Psychology: Applied

Journal of Experimental Psychology: General (2)

Journal of the Indian Academy of Applied Psychology (2)

Journal of the Learning Sciences

Journal of Management Education

Journal of Marketing Education

Journal of Mathematical Behavior (2)

Journal of Neuroscience

Journal of Problem Solving (3)

Journal of Psychology: Interdisciplinary and Applied

Journal for Research in Mathematics Education

Journal of School Psychology

Judgment and Decision Making (3)

Knowledge-Based Systems

Korean Journal of Thinking \& Problem Solving (3)

Learning Disability Quarterly

Learning and Individual Differences (6)

Learning and Instruction (2)

Mathematical Thinking and Learning (2)

Memory

Memory \& Cognition (3)

Metacognition and Learning

Montana Mathematics Enthusiast (2)

Neural Computation

Neurocase

Neurocomputing

Neuropsychologia (2)

Neuropsychological Rehabilitation

Neuroreport

Neuroscience and Behavioral Physiology

Personality and Individual Differences

Problems, Resources, and Issues in Mathematics Undergraduate Studies (2)

Proceedings of the National Academy of Sciences of the United States of America

- volume 2, no. 1 (Spring 2009) 
Psychological Research (2)

Psychology of Aesthetics, Creativity, and the Arts

Psychonomic Bulletin \& Review

Quarterly Journal of Experimental Psychology

Review of General Psychology

Swiss Journal of Psychology

Thinking \& Reasoning

Training and Education in Professional Psychology

Voprosy Psychologii

\section{Bibliography}

\section{General}

Anderson, J.R. (2008) The algebraic brain. In: Gluck, M.A., Anderson, J.R., Kosslyn, S.M. (Eds). Memory and mind:A festschrift for Gordon H.Bower. (pp.75-92). Mahwah, NJ:Lawrence Erlbaum.

Andre, D. \& Fernand, G. (2008) Sherlock Holmes-An expert's view of expertise. British Journal of Psychology, 99, 109-125.

Ardila, A. (2008) On the evolutionary origins of executive functions. Brain and Cognition, 68, 92-99.

Ash, I.K.\&Wiley, J. (2008) Hindsight bias in insight and mathematical problem solving:Evidence of different reconstruction mechanisms for metacognitive versus situational judgments. Memory \& Cognition, 36, 822-837.

Augustinova, M. (2008) Falsification cueing in collective reasoning: Example of the Wason selection task. European Journal of Social Psychology, 38, 770-785.

Bernstein, D.A. \& Lucas, S.G. (2008) Functional fixedness in problem solving. In: Benjamin, L.T. (Ed). Favorite activities for the teaching of psychology. (pp. 143-144). Washington, DC: American Psychological Association.

Bilalic, M., McLeod, P.\& Gobet, F. (2008) Why good thoughts block better ones:The mechanism of the pernicious Einstellung (set) effect. Cognition, 108, 652-661.

Bilalic, M.,McLeod,P.\& Gobet, F.(2008) Inflexibility of experts-Reality or myth? Quantifying the Einstellung effect in chess masters. Cognitive Psychology, 56, 73-102.

Buhner, M., Kroner, S.\& Ziegler, M. (2008) Working memory, visual-spatial-intelligence and their relationship to problem-solving. Intelligence, 36, 672-680.

Campbell, J.I.D. (2008) Subtraction by addition. Memory \& Cognition, 36, 1094-1102.

Carder,H.P., Handley, S.J.\& Perfect,T.J. (2008) Counterintuitive and alternative moves choice in the Water Jug task. Brain and Cognition, 66, 11-20.

Chronicle, E.P., MacGregor, J.N., Lee, M., Ormerod, T.C. and Hughes, P. (2008) Individual Dif- 
ferences in Optimization Problem Solving:Reconciling Conflicting Results.Journal of Problem Solving, 2(1), 41-49.

Fleck, J.I. (2008) Working memory demands in insight versus analytic problem solving. European Journal of Cognitive Psychology, 20, 1-38.

$\mathrm{Fu}, \mathrm{W}$.-T. (2008) Is a single-bladed knife enough to dissect human cognition? Commentary on Griffiths et al. Cognitive Science, 32, 155-161.

Fu,W.-T.\& Anderson,J.R. (2008) Solving the credit assignment problem:Explicit and implicit learning of action sequences with probabilistic outcomes. Psychological Research, 72, 321-330.

Gaissmaier,W., Schooler, L.J.\& Mata, R. (2008) An ecological perspective to cognitive limits: Modeling environment-mind interactions with ACT-R.Judgment and Decision Making, 3, 278-291.

Goldman, B.A.\& Mitchell, D.F. (2008) Problem solving and reasoning. Goldman, B.A.\& Mitchell, D.F. (Eds). Directory of unpublished experimental mental measures. Vol 9. Washington, DC: American Psychological Association.

Gonzalez-Vallejo, C., Lassiter, G.., Bellezza, F.S. \& Lindberg, M.J. (2008) "Save angels perhaps": A critical examination of unconscious thought theory and the deliberation-withoutattention effect. Review of General Psychology, 12, 282-296.

Goode, M.K., Geraci, L. \& Roediger, H.L. (2008) Superiority of variable to repeated practice in transfer on anagram solution. Psychonomic Bulletin \& Review, 15, 662-666.

Grattan-Guinness, I. (2008) Levels of criticism: Handling Popperian problems in a Popperian way. Axiomathes: An International Journal in Ontology \& Cognitive Systems, 18, 37-48.

Griffiths, T.L., Christian, B.R.\& Kalish, M.L.(2008) Using category structures to test iterated learning as a method for identifying inductive bases. Cognitive Science, 32, 68-107.

Guskova, A.V.(2008) The role of the model of the psychological in solving intellectual problems. Voprosy Psychologii, No 1, 26-35.

Kaller, C.P., Rahm, B., Spreer, J., Mader, I. \& Unterrainer, J.M. (2008) Thinking around the corner: The development of planning abilities. Brain and Cognition, 67, 360-370.

Koedinger, K.R., Alibali, M.W. \& Nathan, M.M. (2008). Trade-offs between grounded and abstract representations: Evidence from algebra problem solving. Cognitive Science, 32, 366-397.

Liu, D.-Z. \& Huang, X.-T. (2008) Training on shortcut strategy and its delayed result. Acta Psychologica Sinica, 40, 47-53.

Lyon, D.R., Gunzelmann, G.\& Gluck, K.A. (2008) A computational model of spatial visualization capacity. Cognitive Psychology, 57, 122-152.

MacGregor, J.N. \& Cunningham, J.B. (2008) Rebus puzzles as insight problems. Behavior Research Methods, 40, 263-268.

Maglio, P.P., Wenger, M.J. \& Copeland, A.M. (2008) Evidence for the role of self-priming in epistemic action: Expertise and the effective use of memory. Acta Psychologica, 127, 72-88.

- volume 2, no. 1 (Spring 2009) 
Neace,W.P., Michaud, S., Bolling, L.,Deer, K.\& Zecevic, L. (2008) Frequency formats, probability formats, or problem structure? A test of the nested-sets hypothesis in an extensional reasoning task. Judgment and Decision Making, 3, 140-152.

Newell, B.R. \& Broder, A. (2008) Cognitive processes, models and metaphors in decision research. Judgment and Decision Making, 3, 195-204.

Novick, LR. \& Sherman, S.J. (2008) The effects of superficial and structural information on online problem solving for good versus poor anagram solvers. Quarterly Journal of Experimental Psychology, 61, 1098-1120.

Ollinger, M., Jones, G. \& Knoblich, G. (2008) Investigating the effect of mental set on insight problem solving. Experimental Psychology, 55, 269-282.

Osman, M. (2008) Seeing is as Good as Doing. Journal of Problem Solving, 2(1), 29-40.

Osman, M. (2008) Observation can be as effective as action in problem solving. Cognitive Science, 32, 162-183.

Osman, M. (2008) Positive transfer and negative transfer/antilearning of problem-solving skills. Journal of Experimental Psychology: General, 137, 97-115.

Pe, M.L., Tan, A.-G. \& Heller, K.A. (2008) Affect and successful performance: A study on the Tower of Hanoi and nine-dot. Korean Journal of Thinking \& Problem Solving, 18, 93103.

Perfect,T.J.\&Stark, L.-J.(2008) Why do I always have the best ideas? The role of idea quality in unconscious plagiarism. Memory, 16, 386-394.

Picciuto, E. \& Carruthers, P. (2008) Creativity explained? Evolutionary Psychology, 6, 427431.

Pretz, J.E. (2008) Intuition versus analysis: Strategy and experience in complex everyday problem solving. Memory \& Cognition, 36, 554-566.

Reyna, V.F. \& Brainerd, C.J. (2008) Numeracy, ratio bias, and denominator neglect in judgments of risk and probability. Learning and Individual Differences, 18, 89-107.

Saalweachter, J. \& Pizlo, Z. (2008) Non-Euclidean Traveling Salesman Problem. In: T. Kugler,

J.C. Smith, Y-J. Sun, T. Connolly, Decision Modeling and Behavior in Complex and Uncertain Environments. NY:Springer (pp. 339-358).

Siegala, M. \& Varley, R. (2008) If we could talk to the animals. Behavioral and Brain Sciences, 31, 146-147.

Stupple, E.J.N. \& Ball, L.J. (2008) Belief-logic conflict resolution in syllogistic reasoning: Inspection-time evidence for a parallel-process model. Thinking \& Reasoning, 14, 168-181.

Taatgen, N.A., Huss, D., Dickison, D. \& Anderson, J.R. (2008) The acquisition of robust and flexible cognitive skills. Journal of Experimental Psychology: General, 137, 548-565.

Tak, S.,Plaisier, M.\& van Rooij,I.(2008) Some Tours are More Equal than Others:The ConvexHull Model Revisited with Lessons for Testing Models of the Traveling Salesperson Problem. Journal of Problem Solving, 2(1), 4-28. 
Tan, A.-G. \& Heller, K.A. (2008) The new dimension of thinking. Korean Journal of Thinking \& Problem Solving, 18, 5-6.

Treffinger, D.J., Selby, E.C.\& Isaksen, S.G. (2008) Understanding individual problem-solving style: A key to learning and applying creative problem solving. Learning and Individual Differences, 18, 390-401.

Tubau, E. (2008) Enhancing probabilistic reasoning: The role of causal graphs, statistical format and numerical skills. Learning and Individual Differences, 18, 187-196.

Unterrainer, J.M., Rauss, K.S., Kaller, C.P., Leonhart, R. \& Rahm, B. (2008) Perceived conflicts and errors in complex problem solving. Journal of Clinical and Experimental Neuropsychology, 30, 816-827.

Wichert, A., Pereira, J.D.\& Carreira, P.Visual search light model for mental problem solving. Neurocomputing: An International Journal, 71, 2806-2822.

Zhou, B. \& Yao, Y. (2008) A logic approach to granular computing. International Journal of Cognitive Informatics and Natural Intelligence, 2, 63-79.

\section{Developmental}

Barrouillet, P., Mignon, M. \& Thevenot, C. (2008) Strategies in subtraction problem solving in children. Journal of Experimental Child Psychology, 99, 233-251.

Chavajay, P. (2008) Organizational patterns in problem solving among Mayan fathers and children. Developmental Psychology, 44, 882-888.

Chen, Z. \& Klahr, D. (2008) Remote transfer of scientific-reasoning and problem-solving strategies in children. Kail, R.V. (Ed) Advances in child development and behavior, Vol 36. (pp. 419-470). San Diego, CA: Elsevier Academic Press.

Dellenbach, M.\& Zimprich, D. (2008) Typical intellectual engagement and cognition in old age. Aging, Neuropsychology, and Cognition, 15, 208-231.

Hoppmann, C.A., Coats, A.H. \& Blanchard-Fields, F. (2008) Goals and everyday problem solving:Examining the link between age-related goals and problem-solving strategy use. Aging, Neuropsychology, and Cognition, 15, 401-423.

Imbo, I. \& Vandierendonck, A. (2008) Effects of problem size, operation, and workingmemory span on simple-arithmetic strategies: Differences between children and adults? Psychological Research, 72, 331-346.

Lemaire, P. \& Arnaud, L. (2008) Young and older adults' strategies in complex arithmetic. American Journal of Psychology, 121, 1-16.

Luwel, K., Siegler, R.S. \& Verschaffel, L. (2008) A microgenetic study of insightful problem solving. Journal of Experimental Child Psychology, 99, 210-232.

Madhavi,L.M.(2008) Creating opportunities for improving problem solving skills in infants with developmental delays. Journal of the Indian Academy of Applied Psychology, 34, 101-106.

Maker, C.J.,Jo, S.\& Muammar, O.M. (2008) Development of creativity:The influence of vary-

- volume 2, no. 1 (Spring 2009) 
ing levels of implementation of the DISCOVER curriculum model, a non-traditional pedagogical approach. Learning and Individual Differences, 18, 402-417.

Miller, L.M.S.\& Gagne,D.D. (2008) Adult age differences in reading and rereading processes associated with problem solving.International Journal of Behavioral Development, 32, 34-45.

Omiya, A. (2008) The development of indeterminate reasoning in early childhood.Japanese Journal of Psychology, 79, 1-8.

Rittle-Johnson, B.\& Kmicikewycz, A.O. (2008) When generating answers benefits arithmetic skill: The importance of prior knowledge. Journal of Experimental Child Psychology, 101, 75-81.

Rittle-Johnson, B., Saylor, M.\& Swygert, K.E. (2008) Learning from explaining:Does it matter if mom is listening? Journal of Experimental Child Psychology, 100, 215-224.

Rogers, J.P. (2008) Cardinal number and its representation: Skills, concepts and contexts. Early Child Development and Care, 178, 221-225.

Singer-Freeman, K.E. \& Bauer, P.J. (2008) The ABCs of analogical abilities: Evidence for formal analogical reasoning abilities in 24-month-olds. British Journal of Developmental Psychology, 26, 317-335.

Tranter, L.J.\& Koutstaal,W.(2008) Age and flexible thinking:An experimental demonstration of the beneficial effects of increased cognitively stimulating activity on fluid intelligence in healthy older adults. Aging, Neuropsychology, and Cognition, 15, 184-207.

Xin,Z.Fourth- through sixth-grade students'representations of area-of-rectangle problems: Influences of relational complexity and cognitive holding power. Journal of Psychology: Interdisciplinary and Applied, 142, 581-600.

\section{Education}

Akinsola, M. K. (2008) Relationship of some psychological variables in predicting problem solving ability of in-service mathematics teachers. Montana Mathematics Enthusiast, 5,79-100.

Andersson, U. (2008) Mathematical competencies in children with different types of learning difficulties. Journal of Educational Psychology, 100, 48-66.

Armstrong, A.C. (2008) The fragility of group flow: The experiences of two small groups in a middle school mathematics classroom. Journal of Mathematical Behavior, 27, 101-115.

Burks, R., Lindquist, J. \& McMurran, S. (2008) What's my math course got to do with biology? PRIMUS: Problems, Resources, and Issues in Mathematics Undergraduate Studies, 18, 71-84.

Burns, M.K., Peters, R. \& Noell, G.H. (2008) Using performance feedback to enhance implementation fidelity of the problem-solving team process.Journal of School Psychology, 46, 537-550. 
Chiu, M.M. (2008) Flowing toward correct contributions during group problem solving: A statistical discourse analysis. Journal of the Learning Sciences, 17, 415-463.

Chiu, M.M. (2008) Effects of argumentation on group micro-creativity:Statistical discourse analyses of algebra students' collaborative problem solving. Contemporary Educational Psychology, 33, 382-402.

Diamond, N., Koernig, S.K. \& Iqbal, Z. (2008) Uniting active and deep learning to teach problem-solving skills: Strategic tools and the learning spiral. Journal of Marketing Education, 30, 116-129.

Fuchs, L.S., Compton, D.L., Fuchs, D., Hollenbeck, K.N., Craddock, C.F. \& Hamlett, C.L. (2008) Dynamic assessment of algebraic learning in predicting third graders' development of mathematical problem solving. Journal of Educational Psychology, 100, 829-850.

Fuchs, L.S., Fuchs, D., Stuebing, K., Fletcher, J.M., Hamlett, C.L. \& Lambert, W. (2008) Problem solving and computational skill: Are they shared or distinct aspects of mathematical cognition? Journal of Educational Psychology, 100, 30-47.

Heffernan, N.T., Koedinger, K.R. \& Razzaq, L. (2008). Expanding the model-tracing architecture: $\mathrm{A} 3^{\text {rd }}$ generation intelligent tutor for algebra symbolization. International Journal of Artificial Intelligence in Education, 18, 153-178.

Humberstone, J. \& Reeve, R.A. (2008) Profiles of algebraic competence. Learning and Instruction, 18, 354-367.

Hurts, K. (2008) Building cognitive support for the learning of long division skills using progressive schematization:Design and empirical validation.Computers \& Education, 50, 1141-1156.

Inoue, N. (2008) Minimalism as a guiding principle: Linking mathematical learning to everyday knowledge. Mathematical Thinking and Learning, 10, 36-67.

Irwing, P., Hamza, A., Khaleefa, O. \& Lynn, R. (2008) Effects of Abacus training on the intelligence of Sudanese children. Personality and Individual Differences, 45, 694-696.

Jermann, P. \& Dillenbourg, P. (2008) Group mirrors to support interaction regulation in collaborative problem solving. Computers \& Education, 51, 279-296.

Kapur, M. (2008) Productive failure. Cognition and Instruction, 26, 379-424.

Kapur, M., Voiklis, J. \& Kinzer, C.K. (2008) Sensitivities to early exchange in synchronous computer-supported collaborative learning (CSCL) groups. Computers \& Education, 51,54-66.

Kauffman, D.F., Ge, X., Xie, K. \& Chen, C.-H. (2008) Prompting in web-based environments: Supporting self-monitoring and problem solving skills in college students. Journal of Educational Computing Research, 38, 115-137.

Kramarski, B. (2008) Promoting teachers' algebraic reasoning and self-regulation with metacognitive guidance. Metacognition and Learning, 3, 83-99.

Kuruvilla, V.J. \& Mukhopadhyay, B. (2008) Epistemological study to evolve creative learning process for for engineering students. Journal of the Indian Academy of Applied Psychology, 34, 101-109.

- volume 2, no. 1 (Spring 2009) 
Lavigne, N.C., Salkind, S.J.\&Yan,J.(2008) Exploring college students' mental representations of inferential statistics. Journal of Mathematical Behavior, 27, 11-32.

Lazonder, A.W.\& Rouet, J.-F. (2008) Information problem solving instruction:Some cognitive and metacognitive issues. Computers in Human Behavior, 24, 753-765.

Le Calvez, F., Giroire,H.\&Tisseau, G. (2008) Design of a learning environment in combinatorics based on problem solving:Modeling activities, problems and errors. International Journal of Artificial Intelligence in Education, 18, 59-94.

Lee, K. \& Peh, Y.X. (2008) Differences in working memory profiles amongst children with low versus average academic performances. Korean Journal of Thinking \& Problem Solving, 18, 21-33.

Mayer, R.E., Griffith, E., Jurkowitz, I.T.N. \& Rothman, D. (2008) Increased interestingness of extraneous details in a multimedia science presentation leads to decreased learning. Journal of Experimental Psychology: Applied, 14, 329-339.

Mayfield, K.H.\& Glenn, I.M. (2008) An evaluation of interventions to facilitate algebra problem solving. Journal of Behavioral Education, 17, 278-302.

Montague, M. (2008) Self-regulation strategies to improve mathematical problem solving for students with learning disabilities. Learning Disability Quarterly, 31, 37-44.

Muis, K.R. (2008) Epistemic profiles and self-regulated learning:Examining relations in the context of mathematics problem solving. Contemporary Educational Psychology, 33, 177-208.

Murata, A. (2008) Mathematics teaching and learning as a mediating process: The case of tape diagrams. Mathematical Thinking and Learning, 10, 374-406.

Pol, H.J., Harskamp, E.G. \& Suhre, C.J.M. (2008) The effect of the timing of instructional support in a computer-supported problem-solving program for students in secondary physics education. Computers in Human Behavior, 24, 1156-1178.

Rosales, J., Orrantia, J., Vicente, S. \& Chamoso, J.M. (2008) Studying mathematics problemsolving classrooms. A comparison between the discourse of in-service teachers and student teachers. Journal of Psychology of Education, 23, 275-294.

Samuelsson, J. (2008) The impact of different teaching methods on students' arithmetic and self-regulated learning skills. Educational Psychology in Practice, 24, 237-250.

Santos-Trigo, M. \& Cristobal-Escalante, C. (2008) Emerging high school students' problem solving trajectories based on the use of dynamic software. Journal of Computers in Mathematics and Science Teaching, 27, 325-340.

Sato, J. (2008) Reducing uncertainty of judgments: A method promoting the application of rules. Japanese Journal of Educational Psychology, 56, 32-43.

Soh, L.-K.\& Blank, T. (2008) Integrating case-based reasoning and meta-learning for a selfimproving intelligent tutoring system. International Journal of Artificial Intelligence in Education, 18, 27-58.

Solimeno, A., Mebane, M.E., Tomai, M. \& Francescato, D. (2008) The influence of students 
and teachers characteristics on the efficacy of face-to-face and computer supported collaborative learning. Computers \& Education, 51, 109-128.

Threlfall,J.\&Hargreaves, M. (2008) The problem-solving methods of mathematically gifted and older average-attaining students. High Ability Studies, 19, 83-98.

Van der Stel,M.\&Veenman,M.V.J.(2008) Relation between intellectual ability and metacognitive skillfulness as predictors of learning performance of young students performing tasks in different domains. Learning and Individual Differences, 18, 128-134.

Van Dooren, W., De Bock, D., Janssens, D. \& Verschaffel, L. (2008) The linear imperative: An inventory and conceptual analysis of students' overuse of linearity.Journal for Research in Mathematics Education, 39, 311-342.

Van Gog, T., Paas, F. \& van Merrienboer, J.J.G. (2008) Effects of studying sequences of process-oriented and product-oriented worked examples on troubleshooting transfer efficiency. Learning and Instruction, 18, 211-222.

Varma, S.\& Schwartz, D.L. (2008) How should educational neuroscience conceptualise the relation between cognition and brain function? Mathematical reasoning as a network process. Educational Research, 50, 149-161.

Vilenius-Tuohimaa, P.M., Aunola, K. \& Nurmi, J.-E. (2008) The association between mathematical word problems and reading comprehension. Educational Psychology, 28, 409-426.

Walraven, A., Brand-gruwel, S. \& Boshuizen, H.P.A. (2008) Information-problem solving: A review of problems students encounter and instructional solutions. Computers in Human Behavior, 24, 623-648.

Wester, S.R., Christianson, H.F., Fouad, N.A. \& Santiago-Rivera, A.L. (2008) Information processing as problem solving: A collaborative approach to dealing with students exhibiting insufficient competence. Training and Education in Professional Psychology, 2,193-201.

Wittwer, J. \& Senkbeil, M. (2008) Is students' computer use at home related to their mathematical performance at school? Computers \& Education, 50, 1558-1571.

Wopereis, I., Brand-Gruwel, S.\&Vermetten, Y.(2008) The effect of embedded instruction on solving information problems. Computers in Human Behavior, 24, 738-752.

Yaman, M., Nerdel,C.\& Bayrhuber,H.(2008) The effects of instructional support and learner interests when learning using computer simulations. Computers \& Education, 51, 1784-1794.

Yanovsky, L. (2008) Some problems of extremes in geometry and construction. PRIMUS: Problems, Resources, and Issues in Mathematics Undergraduate Studies, 18, 207-214.

Zydney, J.M. (2008) Cognitive tools for scaffolding students defining an ill-structured problem. Journal of Educational Computing Research, 38, 353-385.

- volume 2, no. 1 (Spring 2009) 


\section{Applied}

Blumberg, F.C., Rosenthal, S.F.\& Randall, J.D. (2008) Impasse-driven learning in the context of video games. Computers in Human Behavior, 24, 1530-1541.

Bonito, J.A., DeCamp, H. \& Ruppel, E.K. (2008) The process of information sharing in small groups: Application of a local model. Communication Monographs, 75, 136-157.

Brand-Gruwel, S.\& Gerjets, P. (2008) Instructional support for enhancing students'information problem solving ability. Computers in Human Behavior, 24, 615-622.

Caughron, J.J. \& Mumford, M.D. (2008) Project planning:The effects of using formal planning techniques on creative problem-solving.Creativity and Innovation Management, 17, 204-215.

Commons, M. L., Goodheart, E. A., Pekker A., Dawson, T. L., Draney, K, \& Adams, K.M. (2008). Using Rasch scaled stage scores to validate orders of hierarchical complexity of Balance Beam task sequences. Journal of Applied Measurement, 9, 182-199.

Dandurand, F., Shultz, T.R. \& Onishi, K.H. (2008) Comparing online and lab methods in a problem-solving experiment. Behavior Research Methods, 40, 428-434.

Davies, J., Goel, A.K. \& Yaner, P.W. (2008) Proteus:Visuospatial analogy in problem-solving. Knowledge-Based Systems, 21, 636-654.

Goltz,S.M., Hietapelto, A.B., Reinsch, RW.\&Tyrell,S.K.(2008) Teaching teamwork and problem solving concurrently. Journal of Management Education, 32, 541-562.

Harter, C.A. \& Ku, H.-Y. (2008) The effects of spatial contiguity within computer-based instruction of group personalized two-step mathematics word problems. Computers in Human Behavior, 24, 1668-1685.

Heppner, P.P. (2008) Expanding the conceptualization and measurement of applied problem solving and coping: From stages to dimensions to the almost forgotten cultural context. American Psychologist, 63, 805-816.

Hopfield, J.J. (2008) Searching for memories, Sudoku, implicit check bits, and the iterative use of not-always-correct rapid neural computation. Neural Computation, 20, 11191164.

Jurdak, M. (2008) The action map as a tool for assessing situated mathematical problem solving performance. Montana Mathematics Enthusiast, 5, 67-78.

Kluge, A. (2008) What you train is what you get? Task requirements and training methods in complex problem-solving. Computers in Human Behavior, 24, 284-308.

Laughlin, P.R., Carey, H.R. \& Kerr, N.L. (2008) Group-to-individual problem-solving transfer. Group Processes \& Intergroup Relations, 11, 319-330.

Lee, S., Soak, S., Kim, K., Park, H.\& Jeon, M. (2008) Statistical properties analysis of real world tournament selection in genetic algorithms. Applied Intelligence, 28, 195-205.

Liu,C.-C.\&Tsai,C.-C. (2008) An analysis of peer interaction patterns as discoursed by on-line small group problem-solving activity. Computers \& Education, 50, 627-639.

Metallidou, P.\& Platsidou,M.(2008) Kolb's Learning Style Inventory-1985:Validity issues and 
relations with metacognitive knowledge about problem-solving strategies.Learning and Individual Differences, 18, 114-119.

Metrailler,Y.A., Reijnen, E., Kneser, C.\& Opwis, K. (2008) Scientific problem solving in a virtual laboratory: A comparison between individuals and pairs. Swiss Journal of Psychology, 67, 71-83.

Nielsen, B.D., Pickett, C.L. \& Simonton, D.K. (2008) Conceptual versus experimental creativity: Which works best on convergent and divergent thinking tasks? Psychology of Aesthetics, Creativity, and the Arts, 2, 131-138.

Ozcan, E., Bilgin, B. \& Korkmaz, E.E. (2008) A comprehensive analysis of hyper-heuristics. Intelligent Data Analysis, 12, 3-23.

Policastro, C.A., Carvalho, A.C.P.\& Delbem, A.C.B. (2008) A hybrid case adaptation approach for case-based reasoning. Applied Intelligence, 28, 101-119.

Rabinowitz, M. \& Hogan, T.M. (2008) Experience and problem representation in statistics. American Journal of Psychology, 121, 395-407.

Verdine, B.N.,Troseth, G.L., Hodapp, R.M.\& Dykens, E.M. (2008) Strategies and correlates of jigsaw puzzle and visuospatial performance by persons with Prader-Willi syndrome. American Journal on Mental Retardation, 113, 343-355.

\section{Neuroscience}

Alvernhe, A., Van Cauter, T., Save, E. \& Poucet, B. (2008) Different CA1 and CA3 representations of novel routes in a shortcut situation. Journal of Neuroscience, 28, 7324-7333.

Bach,M.-E.,Simpson, E.H., Kahn, L., Marshall,J.J., Kandel, E.R.\& Kellendonk, C. (2008) Transient and selective overexpression of D-sub-2 receptors in the striatum causes persistent deficits in conditional associative learning. Proceedings of the National Academy of Sciences, 105, 16027-16032.

Beversdorf, D.Q., Carpenter, A.L., Miller, R.F., Cios, J.S.\& Hillier, A. (2008) Effect of propranolol on verbal problem solving in autism spectrum disorder. Neurocase, 14, 378-383.

Bishop, S., Fossella, J., Croucher, C.J. \& Duncan, J. (2008) COMT valsuperscript 1-sup-5-sup8 met genotype affects recruitment of neural mechanisms supporting fluid intelligence. Cerebral Cortex, 18, 2132-2140.

Genovesio, A., Tsujimoto, S. \& Wise, S.P. (2008) Encoding problem-solving strategies in prefrontal cortex: Activity during strategic errors. European Journal of Neuroscience, 27, 984-990.

Hampshire, A., Gruszka, A., Fallon, S.J. \& Owen, A.M. (2008) Inefficiency in self-organized attentional switching in the normal aging population is associated with decreased activity in the ventrolateral prefrontal cortex. Journal of Cognitive Neuroscience, 20, 1670-1686.

Jerde, T.A., Lewis, S.M., Goerke, U., Gourtzelidis, P., Tzagarakis, C., Lynch, J., Moeller, S., Van de Moortele, P.-F., Adriany, G., Trangle, J., Ugurbil, K.\& Georgopoulos, A.P.(2008) Ultra-high

- volume 2, no. 1 (Spring 2009) 
field parallel imaging of the superior parietal lobule during mental maze solving. Experimental Brain Research, 187, 551-561.

Kennedy, M.R.T., Coelho, C., Turkstra, L.,Ylvisaker, M., Sohlberg, M.M., Yorkston, K., Chiou, H-H. \& Kan, P.-F. (2008) Intervention for executive functions after traumatic brain injury: A systematic review, meta-analysis and clinical recommendations. Neuropsychological Rehabilitation, 18, 257-299.

Kounios, J., Fleck, J.I., Green, D.L., Payne, L., Stevenson, J.L., Bowden, E.M. \& Jung-Beeman, M. (2008) The origins of insight in resting-state brain activity. Neuropsychologia, 46, 281-291.

Krueger, F., Spampinato, M.V., Pardini, M., Pajevic, S., Wood, J.N., Weiss, G.H., Landgraf, S. \& Grafman,J.(2008) Integral calculus problem solving:An fMRI investigation.Neuroreport: For Rapid Communication of Neuroscience Research, 19, 1095-1099.

Moscovitch,M.(2008) The hippocampus as a"stupid,"domain-specific module:Implications for theories of recent and remote memory, and of imagination. Canadian Journal of Experimental Psychology, 62, 62-79.

Prigatano, G.P., Gray, J.A. \& Gale, S.D. (2008) Individual case analysis of processing speed difficulties in children with and without traumatic brain injury. Clinical Neuropsychologist, 22, 603-619.

Qiu, J., Li, H., Jou, J., Wu, Z. \& Zhang, Q. (2008) Spatiotemporal cortical activation underlies mental preparation for successful riddle solving: An event-related potential study. Experimental Brain Research, 186, 629-634.

Qiu, J., Li, H., Yang, D., Luo, Y., Li, Y., Wu, Z.\& Zhang, Q. (2008) The neural basis of insight problem solving: An event-related potential study. Brain and Cognition, 68, 100-106.

Ravizza, S.M., Anderson, J.R. \& Carter, C.S. (2008) Errors of mathematical processing: The relationship of accuracy to neural regions associated with retrieval or representation of the problem state. Brain Research, 1238, 118-126.

Stocco,A.\&Anderson,J.R.(2008) Endogenous control and task representation:An fMRI study in algebraic problem-solving. Journal of Cognitive Neuroscience, 20, 1300-1314.

Thomas, E., Snyder, P.J., Pietrzak, R.H., Jackson, C.E., Bednar, M. \& Maruff, P. (2008) Specific impairments in visuospatial working and short-term memory following low-dose scopolamine challenge in healthy older adults. Neuropsychologia, 46, 2476-2484.

Tranel, D., Manzel, K. \& Anderson, S.W. (2008) Is the prefrontal cortex important for fluid intelligence? A neuropsychological study using matrix reasoning. Clinical Neuropsychologist, 22, 242-261.

\section{Animal}

Cronin, K.A. \& Snowdon, C.T. (2008) The effects of unequal reward distributions on cooperative problem solving by cottontop tamarins, Saguinus oedipus. Animal Behaviour, 75, 245-257. 
De Mendonca-Furtado,O.\& Ottoni, E.B.(2008) Learning generalization in problem solving by a blue-fronted parrot (Amazona aestiva). Animal Cognition, 11, 719-725.

Grand, C. \& Honey, R.C. (2008) Solving XOR. Journal of Experimental Psychology: Animal Behavior Processes, 34, 486-493.

Grigor'ev, N.R., Batalova, T.A., Kirichenko, E.F., Sergievich, A.A. \& Cherbikova, G.E. (2008) Typological features in the behavior of rats. Neuroscience and Behavioral Physiology, 38, 597-603.

Girndt, A., Meier,T.\& Call, J.(2008) Task constraints mask great apes' ability to solve the traptable task. Journal of Experimental Psychology: Animal Behavior Processes, 34, 54-62.

Herrmann, E., Wobber, V.\& Call, J. (2008) Great apes' (Pan troglodytes, Pan paniscus, Gorilla gorilla, Pongo pygmaeus) understanding of tool functional properties after limited experience. Journal of Comparative Psychology, 122, 220-230.

Irie-Sugimoto, N., Kobayashi, T., Sato, T. \& Hasegawa, T. (2008) Evidence of means-end behavior in Asian elephants (Elephas maximus). Animal Cognition, 11, 359-365.

Laidre,M.E.(2008) Spontaneous performance of wild baboons on three novel food-access puzzles. Animal Cognition, 11, 223-230.

Marshall-Pescini, S., Valsecchi, P., Petak, I., Accorsi, P.A. \& Previde, E.P. (2008) Does training make you smarter? The effects of training on dogs' performance (Canis familiaris) in a problem solving task. Behavioural Processes, 78, 449-454.

\section{Books}

Adams, D. \& Hamm, M. (2008) Helping students who struggle with math and science: $A$ collaborative approach for elementary and middle schools. Lanham, MD: Rowman \& Littlefield Education.

Anderson, V., Jacobs, R. \& Anderson, P.J. (2008) Executive functions and the frontal lobes: A lifespan perspective. Philadelphia, PA:Taylor \& Francis.

Engel, C. \& Singer, W. (2008) Better than conscious? Decision making, the human mind, and implications for institutions. Cambridge, MA: MIT Press.

Jager, J. (2008) Handbook of transdisciplinary research. New York, NY: Springer Science + Business Media.

Kugler, T., Smith, J.C., Sun, Y-J. \& Connolly, T. (2008) Decision Modeling and Behavior in Complex and Uncertain Environments. NY:Springer.

Purves, D., Brannon, E.M., Cabeza, R., Huettel, S.A., LaBar, K.S., Platt, M.L. \& Woldorff, M.G. (2008) Principles of cognitive neuroscience. Sunderland, MA: Sinauer Associates.

Sternberg, R., Kaufman, J.C. \& Grigorenko, E.L. (2008) Applied intelligence. New York, NY: Cambridge University Press.

Willoughby, T. \& Wood, E. (2008) Children's learning in a digital world. Malden: Blackwell Publishing.

- volume 2, no. 1 (Spring 2009) 


\section{Dissertations}

\section{General}

Bowyer, D. Evaluation of the effectiveness of triz concepts in non-technical problem-solving utilizing a problem solving guide. Dissertation Abstracts International Section A: Humanities and Social Sciences. Vol 69(1-A), 2008, pp. 276.

Choi, K. Group cognitive complexity:A group-as-a-whole perspective. Dissertation Abstracts International Section A: Humanities and Social Sciences. Vol 69(4-A), 2008, pp. 1433.

$\mathrm{Chu}, \mathrm{Y}$. Human insight problem solving: Performance, processing, and phenomenology. Dissertation Abstracts International:Section B:The Sciences and Engineering.Vol 68(11B), 2008, pp. 7688.

Cole, J.E. Thinking about geometry problem solving. Dissertation Abstracts International Section A:Humanities and Social Sciences. Vol 68(9-A), 2008, pp. 3798.

Derbentseva, N. The intensity of the insight experience in problem solving: Structural and dynamic properties. Dissertation Abstracts International:Section B:The Sciences and Engineering. Vol 68(11-B), 2008, pp. 7707.

Fayena Tawil, F.A problem solving approach to understanding thought processes in a creative task: A protocol analysis comparison of artists and non-artists. Dissertation Abstracts International:Section B:The Sciences and Engineering. Vol 68(10-B), 2008, pp. 7006.

Gao, $\mathrm{H}$. The effects of key concepts availability and individual preparation in the form of proposition formation in collaborative concept mapping on learning, problem solving, and learner attitudes. Dissertation Abstracts International Section A:Humanities and Social Sciences. Vol 69(2-A), 2008, pp. 503.

Hall, T.S. Improving self-efficacy in problem solving: Learning from errors and feedback. Dissertation Abstracts International Section A: Humanities and Social Sciences. Vol 69(4-A), 2008, pp. 1266.

Huttenlock, T.L. Use of an advance organizer in the ill-structured problem domain of information seeking: A comparative case study. Dissertation Abstracts International Section A: Humanities and Social Sciences. Vol 69(2-A), 2008, pp. 578.

Kessell, A.M. Cognitive methods for information visualization: Linear and cyclical events. Dissertation Abstracts International: Section B: The Sciences and Engineering. Vol 69(4-B), 2008, pp. 2648.

Kim,Y.H. Rebounding from learned helplessness: A measure of academic resilience using anagrams. Dissertation Abstracts International:Section B:The Sciences and Engineering. Vol 68(10-B), 2008, pp. 6947.

Kittell, D.D. Sleuthing: Using the key-word clues strategy to identify arithmetical operations when solving mathematical word problems. Dissertation Abstracts International Section A:Humanities and Social Sciences. Vol 68(8-A), 2008, pp. 3308.

Kittur, A. Feature-based vs. relational category learning: $A$ dual process view. Dissertation Abstracts International: Section B: The Sciences and Engineering. Vol 69(1-B), 2008, pp. 710. 
Meszaros, M.Multiattribute judgment and nonconscious cognition: Further characterization of the deliberation-without-attention effect. Dissertation Abstracts International:Section B:The Sciences and Engineering. Vol 68(9-B), 2008, pp. 6351.

Paritosh, P.K. Back of the envelope reasoning for robust quantitative problem solving. Dissertation Abstracts International:Section B:The Sciences and Engineering.Vol 68(11-B), 2008, pp. 7446.

Pfeil, J.C. Indicators of recursive thinking: An exploration of two approaches to measuring aptitude in recursion. Dissertation Abstracts International Section A: Humanities and Social Sciences. Vol 69(3-A), 2008, pp. 916.

Richmond, D. Lessons learned from designing a comprehensive case-based reasoning (CBR) tool for support of complex thinking. Dissertation Abstracts International Section A: Humanities and Social Sciences. Vol 69(4-A), 2008, pp. 1337.

Walinga, J. The power of focus: Unlocking creative insight and overcoming performance barriers. Dissertation Abstracts International: Section B:The Sciences and Engineering. Vol 69(3-B), 2008, pp. 1935.

Weckbacher, L.M.. The role of visualization in geometric problem solving. Dissertation Abstracts International Section A: Humanities and Social Sciences. Vol 68(10-A), 2008, pp. 4202.

Wei, H. Solving continuous space location problems. Dissertation Abstracts International Section A:Humanities and Social Sciences. Vol 69(2-A), 2008, pp. 709.

\section{Developmental}

Abdellatif, H.R. Analogical reasoning in elementary school children: The role of age and relational knowledge. Dissertation Abstracts International: Section B: The Sciences and Engineering. Vol 69(1-B), 2008, pp. 713.

Boudreaux, M.K. An analysis of metacognitive reading strategies and the academic performance of middle school students. Dissertation Abstracts International Section A: Humanities and Social Sciences. Vol 69(5-A), 2008, pp. 1716.

Bushman, B.B.Does teaching problem-solving skills matter? An evaluation of problem-solving skills training for the treatment of social behavioral problems in children. Dissertation Abstracts International: Section B: The Sciences and Engineering. Vol 68(9-B), 2008, pp. 6292.

Edwards-Omolewa, N.D.Elementaryschool children's strategy use and strategy preferences on multidigit addition and subtraction story problems. Dissertation Abstracts International Section A:Humanities and Social Sciences. Vol 68(8-A), 2008, pp. 3317.

Fagan, Y.M. An analysis of 2005 NAEP 8th grade mathematics achievement items by content strand, problem type and language complexity. Dissertation Abstracts International Section A:Humanities and Social Sciences. Vol 69(1-A), 2008, pp. 148.

Herron, J. Culturally relevant word problems: The effects on second graders' mathematics achievement. Dissertation Abstracts International Section A: Humanities and Social Sciences. Vol 68(7-A), 2008, pp. 2819.

- volume 2, no. 1 (Spring 2009) 
Mueller, M. A study of the development of reasoning in sixth grade students. Dissertation Abstracts International Section A: Humanities and Social Sciences. Vol 68(7-A), 2008, pp. 2866.

Myers, A. Factors that predict the use of metacognitive strategies in the middle school classroom. Dissertation Abstracts International Section A:Humanities and Social Sciences. Vol 69(5-A), 2008, pp. 1671.

Okita, S.Y.Learn wisdom by the folly of others: Children learning to self correct by monitoring the reasoning of projective pedagogical agents. Dissertation Abstracts International Section A:Humanities and Social Sciences. Vol 69(5-A), 2008, pp. 1745.

\section{Education}

Bessick, S.C.Improved critical thinking skills as a result of direct instruction and their relationship to academic achievement. Dissertation Abstracts International Section A:Humanities and Social Sciences. Vol 69(3-A), 2008, pp. 870.

Bieniek, V.Y. Implementation of a cognitive apprenticeship model on student programming and perception of problem-solving ability: An exploratory study. Dissertation Abstracts International Section A: Humanities and Social Sciences. Vol 69(1-A), 2008, pp. 187.

Bixler, B.A.. The effects of scaffolding student's problem-solving process via question prompts on problem solving and intrinsic motivation in an online learning environment. Dissertation Abstracts International Section A: Humanities and Social Sciences. Vol 68(10-A), 2008, pp. 4261.

Bradford, S.M. The use of mathematics dialogues to support student learning in high school prealgebra classes. Dissertation Abstracts International Section A: Humanities and Social Sciences. Vol 68(9-A), 2008, pp. 3772.

Burns-Sardone, N.L. An investigation of the relationship between higher education learning environments and learner characteristics to the development of information technology fluency and course satisfaction. Dissertation Abstracts International Section A:Humanities and Social Sciences. Vol 69(3-A), 2008, pp. 854.

Cobanoglu Aktan, D. Investigation of the relationship between students'problem solving and conceptual understanding of electricity. Dissertation Abstracts International Section A: Humanities and Social Sciences. Vol 68(11-A), 2008, pp. 4653.

Cuneo, A. Examining the effects of collaborative learning on performance in undergraduate mathematics. Dissertation Abstracts International Section A: Humanities and Social Sciences. Vol 68(11-A), 2008, pp. 4586.

Duke, V.C. Technology and math:The relationship between using computers in the fifth grade and demonstrating math competencies. Dissertation Abstracts International Section A: Humanities and Social Sciences. Vol 68(9-A), 2008, pp. 3772.

Edinger, M.J. An exploratory study of creativity-fostering teacher behaviors in secondary classrooms. Dissertation Abstracts International Section A: Humanities and Social Sciences. Vol 69(3-A), 2008, pp. 928. 
Eren Artan, A. Case-based discussions in an educational psychology course: Problem solving processes and interactions. Dissertation Abstracts International Section A:Humanities and Social Sciences. Vol 69(2-A), 2008, pp. 502.

Hartman, P.A.Comparing students with mathematics learning disabilities and students with low mathematics achievement in solving mathematics word problems. Dissertation Abstracts International Section A:Humanities and Social Sciences.Vol 68(12-A), 2008, pp. 5030.

Hirsch, J. Tracking changes in teaching and learning abstract algebra: Beliefs and ability to abstract. Dissertation Abstracts International Section A: Humanities and Social Sciences. Vol 69(1-A), 2008, pp. 149.

Humphrey, M. Mathematical word problem solving performance of students in an alternative setting: Investigating contributing factors and intervention. Dissertation Abstracts International Section A:Humanities and Social Sciences. Vol 69(6-A), 2008, pp. 2220.

Kohl, P.B. Towards an understanding of how students use representations in physics problem solving. Dissertation Abstracts International Section A:Humanities and Social Sciences. Vol 68(7-A), 2008, pp. 2883.

$\mathrm{Ku}, \mathrm{W} . \mathrm{A}$. Using concept maps to explore the conceptual knowledge of technology students: An exploratory study. Dissertation Abstracts International Section A: Humanities and Social Sciences. Vol 68(10-A), 2008, pp. 4225.

Lajinian, A.A. The effect of visually enhanced instructional units on high school calculus students' visualization ability and their understanding of the limit concept. Dissertation Abstracts International Section A:Humanities and Social Sciences. Vol 69(5-A), 2008, pp. 1710.

Mathew, E. Learning physics: A comparative analysis between instructional design methods. Dissertation Abstracts International Section A: Humanities and Social Sciences. Vol 69(5-A), 2008, pp. 1696.

Peters, E.E. The effect of nature of science metacognitive prompts on science students'content and nature of science knowledge, metacognition, and self-regulatory efficacy. Dissertation Abstracts International Section A: Humanities and Social Sciences. Vol 68(8-A), 2008, pp. 3283.

Phillips, A.P. An interactional discourse analysis of strategies used by engineering students during problem solving activities. Dissertation Abstracts International: Section B:The Sciences and Engineering. Vol 69(4-B), 2008, pp. 2649.

Rosengrant, D.R. Multiple representations and free-body diagrams: Do students benefit from using them? Dissertation Abstracts International Section A: Humanities and Social Sciences. Vol 68(7-A), 2008, pp. 2884.

Schwaner, C.A. Observations of the logical sequence of problem solving as perceived by students in college mathematics courses. Dissertation Abstracts International Section A: Humanities and Social Sciences. Vol 68(8-A), 2008, pp. 3268.

Smith, C.E. On students' conceptualization of combinatorics: A multiple case study. Disserta-

- volume 2, no. 1 (Spring 2009) 
tion Abstracts International Section A: Humanities and Social Sciences. Vol 68(7-A), 2008, pp. 2867.

Solazzo, L.A.The role of gender, cognition, anxiety, and competence beliefs in predicting mathematics achievement. Dissertation Abstracts International:Section B:The Sciences and Engineering. Vol 69(2-B), 2008, pp. 1357.

Thompson, K.A.Students' understanding of trigonometry enhanced through the use of a real world problem: Improving the instructional sequence. Dissertation Abstracts International Section A:Humanities and Social Sciences. Vol 68(9-A), 2008, pp. 3777.

Toy, S.Online ill-structured problem-solving strategies and their influence on problem-solving performance. Dissertation Abstracts International Section A: Humanities and Social Sciences. Vol 68(7-A), 2008, pp. 2797.

Vanspronsen, H.D.Proof processes of novice mathematics proof writers. Dissertation Abstracts International Section A: Humanities and Social Sciences. Vol 69(4-A), 2008, pp. 1311.

Walker, C.M. An investigation of how African American community college students with different levels of mathematics anxiety engage in problem solving tasks. Dissertation Abstracts International Section A: Humanities and Social Sciences. Vol 69(2-A), 2008, pp. 545.

Zhang, Z. Cognitive assessment in a computer-based coaching environment in higher education:Diagnostic assessment of development of knowledge and problem-solving skill in statistics. Dissertation Abstracts International Section A: Humanities and Social Sciences. Vol 68(10-A), 2008, pp. 4271.

\section{Applied}

Adams, W.K. Development of a problem solving evaluation instrument; untangling of specific problem solving assets. Dissertation Abstracts International: Section B:The Sciences and Engineering. Vol 69(4-B), 2008, pp. 2367.

Black, T.R. Cognitive apprenticeship and the computer programming student: How do students learn within this framework? Dissertation Abstracts International Section A: Humanities and Social Sciences. Vol 69(1-A), 2008, pp. 156.

Block, G.F.Problem-solving and metacognitive judgments in the mastermind deductive reasoning game. Dissertation Abstracts International:Section B:The Sciences and Engineering.Vol 69(3-B), 2008, pp. 1980.

Burton, C.L.Cognitive ability and inconsistency in reaction time as predictors of everyday problem solving in older adults. Dissertation Abstracts International: Section B:The Sciences and Engineering. Vol 69(3-B), 2008, pp. 1980.

Chan, M.S.-Y. Learning and reasoning about systems through direct-manipulation animation. Dissertation Abstracts International: Section B:The Sciences and Engineering. Vol 69(5B), 2008, pp. 3286 .

Lang, J.(Y.-C.) The effect of presenting worked examples for problem solving in a computer game. Dissertation Abstracts International Section A:Humanities and Social Sciences.Vol 68(10A), 2008, pp. 4263. 
Lawanto, O.Self-appraisal and self-management of cognition and problem difficulty:Relationship and metacognitive changes during an engineering design project. Dissertation Abstracts International Section A: Humanities and Social Sciences.Vol 69(5-A), 2008, pp. 1670.

Lu, J.Supporting medical decision making with collaborative tools. Dissertation Abstracts International Section A:Humanities and Social Sciences. Vol 69(5-A), 2008, pp. 1682.

Neely, T.L. The effects of age, instructions, and problem content on everyday problem-solving outcome using two scoring procedures. Dissertation Abstracts International: Section B: The Sciences and Engineering. Vol 68(7-B), 2008, pp. 4868.

Singh, V. Knowledge creation, sharing and reuse in online technical support for Open Source Software. Dissertation Abstracts International Section A:Humanities and Social Sciences. Vol 69(5-A), 2008, pp. 1581.

Su, Y.-C. Effects of computer game-based instruction on programming achievement of adult students in Taiwan. Dissertation Abstracts International Section A: Humanities and Social Sciences. Vol 69(5-A), 2008, pp. 1747.

Vasconcelos-Santillan, J.Development of a web-based surveying instrument to identify problemsolving abilities related to effective instruction in computer programming. Dissertation Abstracts International: Section B: The Sciences and Engineering. Vol 69(4-B), 2008, pp. 2432.

\section{Neuroscience}

Ladd, H.W. An electrophysiological study of individual human learning. Dissertation Abstracts International:Section B:The Sciences and Engineering.Vol 69(3-B), 2008, pp. 1999.

- volume 2, no. 1 (Spring 2009) 